\title{
Liquid Formulation Using Different Oils and Shelf Life Study of Effective Bacterial Bio-Agents
}

\author{
S.M. Jayasudha*, K.C. Kirankumar, R.K. Mesta and Ramesh Ippikoppa \\ Department of Plant Pathology, University of Horticultural Sciences, \\ Bagalkot-587103, Karnataka, India \\ *Corresponding author
}

\section{A B S T R A C T}

\begin{tabular}{|c|}
\hline Keywords \\
\hline $\begin{array}{l}\text { Bacterial bio- } \\
\text { agents, } \\
\text { Formulation, Shelf } \\
\text { life }\end{array}$ \\
\hline Article Info \\
\hline $\begin{array}{l}\text { Accepted: } \\
\text { 04 March } 2018 \\
\text { Available Online: } \\
\text { 10 April } 2018\end{array}$ \\
\hline
\end{tabular}

Liquid formulation of Bacillus subtilis-KK-9A, Brevibacillus borstelensis-BK-6, Brevibacillus sp-PM-2A, Lysinibacillus xylanilyticus-VK-6B and consortium were developed using distilled water, ground nut oil, nutrient broth, pongamia oil and sunflower oil to enhance the shelf life and efficacy of the biocontrol agent besides easing the delivery of bio-inoculants through micro-irrigation techniques. The highest population level of Bacillus subtilis-KK-9A, Brevibacillus borstelensis-BK-6, Brevibacillus sp-PM-2A and Lysinibacillus xylanilyticus-VK-6B were observed in pongamia oil amended with glycerol even after 3 months of storage. Pongamia oil based formulation was found best formulation followed by ground nut oil, sunflower oil, distilled water, nutrient broth based formulation which retains the highest per cent survival of Bacillus subtilis (45.05), Brevibacillus borstelensis (32.93), Brevibacillus sp (48.80), Lysinibacillus xylanilyticus (60.80), and consortium 31.12 per cent even after 90 days.

\section{Introduction}

Biological management of plant pathogen by antagonistic microorganisms is a potential non chemical means (Harman, 1991) and is known to be a cheap and effective, eco-friendly method for management of crop disease (Cook and Baker, 1983). Some of the bio-control agents like Bacillus subtillis and Pseudomonas fluorescence exhibit inhibition zone and found antagonistic to Xanthomonas axonopodis pv. punicae (Yenjerappa et al., 2013).

In this context biological management of plant pathogen by antagonistic microorganisms is taking upper hand.
When the powder formulations were used for the management of plant diseases in horticultural and plantations crops through micro-irrigation techniques, the concerns are raised on blockage of nozzles and distribution of bio-inoculants. In addition, the process of bio-hardening in horticultural plantlets and tissue culture plants, necessitates the development of liquid-based bio-formulations. In addition, it has been demonstrated that the development of liquid formulation has several advantages including high cell count, zero contamination, longer shelf life, greater protection against environmental stresses and increased field efficacy (Hegde, 2002; Vendan and Thangaraju, 2006). In liquid formulation, 
the microbial organisms are present in a dormant cyst form and after application in the field, the dormant form gives rise to active cells. This helps to increase the shelf life of liquid bioformulation for more than 1 year. So that current research has been conducted on formulation of four effective bio-agents (Bacillus subtilis-KK-9A, Brevibacillus borstelensis-BK-6, Brevibacillus sp-PM-2A and Lysinibacillus xylanilyticus- VK-6B) and consortium by using oils viz., distilled water, ground nut oil, nutrient broth, pongamia oil and sunflower oil.

\section{Materials and Methods}

\section{Bacterial bio-agents}

Four bacterial biocontrol agents viz., Bacillus subtilis-KK-9A, Brevibacillus borstelensisBK-6, Brevibacillus sp-PM-2A and Lysinibacillus xylanilyticus- VK-6B which were previously identified as effective biocontrol agents against Xanthomonas axonopodis pv. Punicae (Ippikoppa, 2015) used in this study.

Efficacy of bacterial bio-agents against $X . a . p$ by agar well diffusion method

The efficacy of these bio-agents were reconfirmed by agar well method it involves making of nutrient broth and before pour into petriplates add X.a.p culture into it, after solidification, an agar plate is punched aseptically with sterile cork borer and volume of the $(20-100 \mu \mathrm{l})$ of culture filtrate is introduced into well. Then, the culture filtrate of each bio-agent can be poured into well and it was incubated at $30^{\circ} \mathrm{C}$ for $48 \mathrm{hr}$.

Procedure for culture preparation and formulation

Bacterial antogonists (Brevibacillus sp-SM1A, Lysinibacillus xylanilyticus-VK-6B,
Brevibacillus borstelensis-BK-6 and Bacillus subtilis-KK-9A) were grown on nutrient broth for $72 \mathrm{hrs}$, on an orbital shaker at $150 \mathrm{rpm}$ at $30{ }^{0} \mathrm{C}$, till the maximum spore yield was produced, these were harvested and subsequently washed by repeated centrifugation at 8,000 rpmfor $20 \mathrm{~min}$ at $4{ }^{\circ} \mathrm{C}$ in sterile distilled water (Warriner and Waites, 1999). Finally, the spore pellet was resuspended in sterile Nutrient broth and used as active material in different formulations. The final spore titer was adjusted to $\geq 10^{8} \mathrm{CFU} / \mathrm{ml}$.

\section{Different types of oils used in liquid formulation}

Distill water, Ground nut oil, NA broth, Pongamia oil, Sunflower oil,

In case of liquid formulation the culture preparation was same in case of powder formulation. However in the preparation of $100 \mathrm{ml}$ of liquid formulation $35 \mathrm{ml}$ of glycerol, $8.5 \mathrm{ml}$ of oil, and $0.1 \%$ Tritan $-\mathrm{x}$ as stabilizer and distill water and pellet mixture in the ratio 3:1 were added. The details were mentioned in the table 1 .

\section{Enumeration of CFU}

The shelf life was determined by enumerating the population of bacterial antagonists by serial dilution Plate method using nutrient agar medium. The dilution was prepared by taking $1 \mathrm{ml}$ of formulation in $9 \mathrm{ml}$ sterilized water, shaken well on orbital spinax for $5 \mathrm{~min}$ and further diluted to get the final dilution of $10^{7}$.

From these dilutions, $0.1 \mathrm{ml}$ was spread on sterilized Petri plates and sterilized media was poured over it. The plates were then given a gentle swirl clockwise and anti-clockwise to distribute the suspension uniformly in the medium. These plates were incubated at $25^{\circ} \mathrm{C}$ and observed regularly for the appearance of microbial colonies. 
The population (cfu/g) was counted by average number of colonies (average of $10^{5}$ $10^{6}$ and $10^{7}$ ) developed in each treatment.

\section{Results and Discussion}

\section{Shelf life of bioagents in liquid formulation}

In case of liquid formulation of Bacillus subtilis, Brevibacillus borstelensis Brevibacillus $s p$ and Lysinibacillus xylanilyticus using distilled water, ground nut oil, nutrient broth, pongamia oil and sunflower oil, the best formulation was pongamia oil based formulation followed by ground nut oil, sunflower oil, distilled water and nutrient broth. The results were depicted in the Figure 1.

\section{Bacillus subtillis}

The shelf life of the Bacillus subtillis in the liquid formulations was tested and the data is presented in the table 2. Among the liquid carriers tested the pongamia oil was found best with the highest colony count even after the 90 days. The initial colony count at the time of first sampling was 45.50 which declined as the number of days proceeded. The colony count recorded was 44.50, 39.50, $33.00,31.50,25.75$ and 20.50 at $15^{\text {th }}, 30^{\text {th }}$, $45^{\text {th }}, 60^{\text {th }}$ and $75^{\text {th }}$ day respectively.

The next best treatment among the tested formulations was groundnut oil, which significantly differed from the pongamia oil. The ground oil formulation recorded 14.50 colonies after the $90^{\text {th }}$ day with the initial count of 45.00 .

The sunflower oil formulation was to found significant with the 8.75 colonies at the $90^{\text {th }}$ day where the initial count recorded was 44.25 .

Though the distilled water and nutrient broth varied significantly they recorded the least colony count of 5.75 and 1.75 respectively after the $90^{\text {th }}$ day with the initial colony count of 43.50 and 46.50 .

The highest survival per cent of 45.05 Bacillus subtillis at $90^{\text {th }}$ day was observed in pongamia oil followed by ground nut oil (32.22per cent), sunflower oil (19.77per cent), distilled water (13.22per cent) and nutrient broth (3.76per cent).

\section{Brevibacillus borstelensis}

The shelf life of Brevibacillus borstelensis in different liquid carrier material were recorded and depicted in the table 3. Among the different liquid formulations tested, pongamia oil recorded the highest colonies at the $90^{\text {th }}$ day (13.50), which was on par with ground nut oil, the initial count of 41.00 and 40.50 were recorded in pongamia oil and groundnut oil respectively. The decline in colonies was observed from initial count to $38.75,32.25$, $24.50,18.25$ and 18.75 respectively in case of pongamia oil.

The other treatment viz., sunflower oil, distilled water and nutrient broth recorded the $7.00,3.50,1.25$ colonies at the $90^{\text {th }}$ day and these values were found significantly different.

Among the different liquid formulation tested for Brevibacillus borstelensis survivability the pongamia oil recorded the highest survival percentage of 32.93 followed by groundnut oil $(28.40 \%)$, sunflower oil $(18.30 \%)$, distilled water (8.48per cent) and nutrient broth (2.96per cent).

\section{Brevibacillus sp}

The Brevibacillus sp tested for its shelf life in the liquid formulations and observations recorded at different intervals are depicted in the table 4. 
Table.1 Treatment details of liquid formulation

\begin{tabular}{|c|c|c|}
\hline $\begin{array}{l}\text { Sl. } \\
\text { No }\end{array}$ & Formulation & Composition for $100 \mathrm{ml}$ formulation \\
\hline 1 & Distill water & $\begin{array}{l}\text { Distilled water and pellet mixture in Nutrient } \\
\text { broth } 3: 1(65 \mathrm{ml}) \text { Glycerol }(35 \mathrm{ml}) \text {; Tritan-X } \\
(0.1 \mathrm{ml})\end{array}$ \\
\hline 2 & $\begin{array}{l}\text { Ground nut oil } \\
\text { based }\end{array}$ & $\begin{array}{l}\text { Ground nut oil }(8.5 \mathrm{ml}) \text {; Glycerol }(35 \mathrm{ml}) \text {; } \\
\text { Tritan-x }(0.1 \mathrm{ml}) \text { Distilled water and pellet } \\
\text { mixture in Nutrient broth }(56.5 \mathrm{~m})\end{array}$ \\
\hline 3 & NA broth & $\begin{array}{l}\text { Nutrient broth }(8.5 \mathrm{ml}) \text {; Distilled water and } \\
\text { pellet mixture in Nutrient broth } 3: 1(56.5 \mathrm{ml})\end{array}$ \\
\hline 4 & Pongamia oil based & $\begin{array}{l}\text { Pongamia oil }(8.5 \mathrm{ml}) \text {; Glycerol }(35 \mathrm{ml}) \text {; Tritan-X } \\
\text { (0. } 1 \mathrm{ml}) \text { Distilled water and pellet mixture in } \\
\text { Nutrient broth } 3: 1(56.5 \mathrm{ml})\end{array}$ \\
\hline 5 & Sunflower oil based & $\begin{array}{l}\text { Sunflower oil }(8.5 \mathrm{ml}) \text {; Glycerol }(35 \mathrm{ml}) \text {; Tritan- } \\
\mathrm{x}(0.1 \mathrm{ml}) \text { Distilled water and pellet mixture in } \\
\text { Nutrient broth } 3: 1(56.5 \mathrm{ml})\end{array}$ \\
\hline
\end{tabular}

Table.2 Shelf life Bacillus subtilis in different oil formulations

\begin{tabular}{|c|c|c|c|c|c|c|c|c|c|}
\hline \multirow{2}{*}{$\begin{array}{l}\text { Sl. } \\
\text { No. }\end{array}$} & \multirow[t]{2}{*}{ Shelf life } & \multicolumn{7}{|c|}{$x 10^{6} \mathrm{CFU} / \mathrm{g}$ of formulation } & \multirow{2}{*}{$\begin{array}{c}\text { Survival } \\
\%\end{array}$} \\
\hline & & 0 day & $\begin{array}{l}15^{\text {th }} \\
\text { day }\end{array}$ & $\begin{array}{l}30^{\text {th }} \\
\text { day }\end{array}$ & $\begin{array}{l}45^{\text {th }} \\
\text { day }\end{array}$ & $\begin{array}{l}60^{\text {th }} \\
\text { day }\end{array}$ & $\begin{array}{l}75^{\text {th }} \\
\text { day }\end{array}$ & $\begin{array}{l}90^{\text {th }} \\
\text { day }\end{array}$ & \\
\hline 1 & Distilledl water & 43.50 & 26.25 & 21.00 & 17.75 & 14.50 & 11.25 & 5.75 & 13.22 \\
\hline 2 & Ground nut oil & 45.00 & 39.50 & 33.50 & 26.75 & 22.50 & 18.25 & 14.50 & 32.22 \\
\hline 3 & Nutrient broth & 46.50 & 39.25 & 18.50 & 11.50 & 6.00 & 2.25 & 1.75 & 3.76 \\
\hline 4 & Pongamia oil & 45.50 & 44.50 & 39.50 & 33.00 & 31.50 & 25.75 & 20.50 & 45.05 \\
\hline 5 & Sunflower oil & 44.25 & 32.25 & 23.25 & 21.75 & 18.50 & 15.25 & 8.75 & 19.77 \\
\hline & SEm \pm & & 0.79 & 1.20 & 1.22 & 0.81 & 1.00 & 0.82 & \\
\hline & CD (0.01) & NS & 3.30 & 5.04 & 5.09 & 3.40 & 4.20 & 3.42 & \\
\hline
\end{tabular}

Table.3 Shelf life Brevibacillus borstelensis in different oil formulations

\begin{tabular}{|c|c|c|c|c|c|c|c|c|c|}
\hline \multirow[t]{2}{*}{ Sl. No. } & \multirow[t]{2}{*}{ Shelf life } & \multicolumn{7}{|c|}{ x $10^{6} \mathrm{CFU} / \mathrm{g}$ of formulation } & \multirow[t]{2}{*}{ Survival\% } \\
\hline & & 0 day & $\begin{array}{l}15^{\text {th }} \\
\text { day }\end{array}$ & $\begin{array}{l}30^{\text {th }} \\
\text { day }\end{array}$ & $\begin{array}{l}45^{\text {th }} \\
\text { day }\end{array}$ & $\begin{array}{l}60^{\text {th }} \\
\text { day }\end{array}$ & $\begin{array}{l}75^{\text {th }} \\
\text { day }\end{array}$ & $90^{\text {th }}$ day & \\
\hline 1 & Distilled water & 41.25 & 21.75 & 17.50 & 15.75 & 13.50 & 9.50 & 3.50 & 8.48 \\
\hline 2 & Ground nut oil & 40.50 & 31.00 & 28.75 & 20.50 & 18.25 & 13.75 & 11.50 & 28.40 \\
\hline 3 & Nutrient broth & 42.25 & 29.50 & 16.25 & 11.50 & 4.75 & 2.75 & 1.25 & 2.96 \\
\hline 4 & Pongamia oil & 41.00 & 38.75 & 32.25 & 24.50 & 18.25 & 18.75 & 13.50 & 32.93 \\
\hline 5 & Sunflower oil & 38.25 & 24.25 & 22.25 & 18.75 & 15.00 & 12.75 & 7.00 & 18.30 \\
\hline & SEm \pm & & 1.29 & 0.91 & 1.03 & 1.04 & 0.55 & 0.62 & \\
\hline & CD (0.01) & & 5.39 & 3.83 & 4.33 & 4.36 & 2.32 & 2.62 & \\
\hline
\end{tabular}


Int.J.Curr.Microbiol.App.Sci (2018) 7(4): 317-324

Table.4 Shelf life of Brevibacillus sp. in different oil formulations

\begin{tabular}{|c|c|c|c|c|c|c|c|c|c|}
\hline \multirow[t]{2}{*}{ Sl. No. } & \multirow[t]{2}{*}{ Shelf life } & \multicolumn{7}{|c|}{$\mathrm{x} 10^{6} \mathrm{CFU} / \mathrm{g}$ of formulation } & \multirow[t]{2}{*}{ Survival \% } \\
\hline & & 0 day & $15^{\text {th }}$ day & $30^{\text {th }}$ day & $45^{\text {th }}$ day & $60^{\text {th }}$ day & $75^{\text {th }}$ day & $90^{\text {th }}$ day & \\
\hline 1 & Distilled water & 40.50 & 20.75 & 14.25 & 11.50 & 11.00 & 7.25 & 4.00 & 9.90 \\
\hline 2 & Ground nut oil & 41.25 & 24.50 & 21.75 & 17.25 & 15.75 & 14.50 & 8.50 & 20.60 \\
\hline 3 & Nutrient broth & 41.75 & 18.75 & 10.50 & 9.50 & 8.00 & 6.50 & 2.00 & 4.80 \\
\hline 4 & Pongamia oil & 41.50 & 33.25 & 31.00 & 25.75 & 25.00 & 21.50 & 20.25 & 48.80 \\
\hline 5 & Sunflower oil & 40.25 & 22.25 & 18.25 & 14.75 & 12.00 & 12.00 & 6.50 & 16.10 \\
\hline & SEm \pm & & 2.01 & 0.80 & 1.03 & 0.99 & 0.66 & 0.97 & \\
\hline & $\mathrm{CD}(0.01)$ & & 8.38 & 3.36 & 4.32 & 4.16 & 2.76 & 4.06 & \\
\hline
\end{tabular}

Table.5 Shelf life of Lysinibacillus xylanilyticus in different oil formulations

\begin{tabular}{|c|c|c|c|c|c|c|c|c|c|}
\hline \multirow[t]{2}{*}{ Sl. No. } & \multirow[t]{2}{*}{ Shelf life } & \multicolumn{7}{|c|}{$\times 10^{6} \mathrm{CFU} / \mathrm{g}$ of formulation } & \multirow[t]{2}{*}{ Survival \% } \\
\hline & & 0 day & $15^{\text {th }}$ day & $30^{\text {th }}$ day & $45^{\text {th }}$ day & $60^{\text {th }}$ day & $75^{\text {th }}$ day & $90^{\text {th }}$ day & \\
\hline 1 & Distilled water & 35.75 & 18.50 & 17.50 & 11.25 & 9.50 & 9.50 & 9.50 & 26.60 \\
\hline 2 & Ground nut oil & 36.75 & 31.75 & 25.25 & 18.50 & 14.75 & 14.75 & 14.75 & 40.10 \\
\hline 3 & Nutrient broth & 38.25 & 31.00 & 16.00 & 6.50 & 3.25 & 2.00 & 1.25 & 3.30 \\
\hline 4 & Pongamia oil & 37.00 & 35.75 & 31.25 & 24.50 & 22.50 & 22.50 & 22.50 & 60.80 \\
\hline 5 & Sunflower oil & 36.25 & 24.50 & 22.50 & 14.25 & 14.00 & 14.00 & 14.00 & 38.60 \\
\hline & SEm \pm & & 0.81 & 0.86 & 1.14 & 0.88 & 0.87 & 0.88 & \\
\hline & $\mathrm{CD}(0.01)$ & & 3.37 & 3.60 & 4.75 & 3.70 & 3.66 & 3.70 & \\
\hline
\end{tabular}

Table.6 Shelf life Consortium in different oil formulations

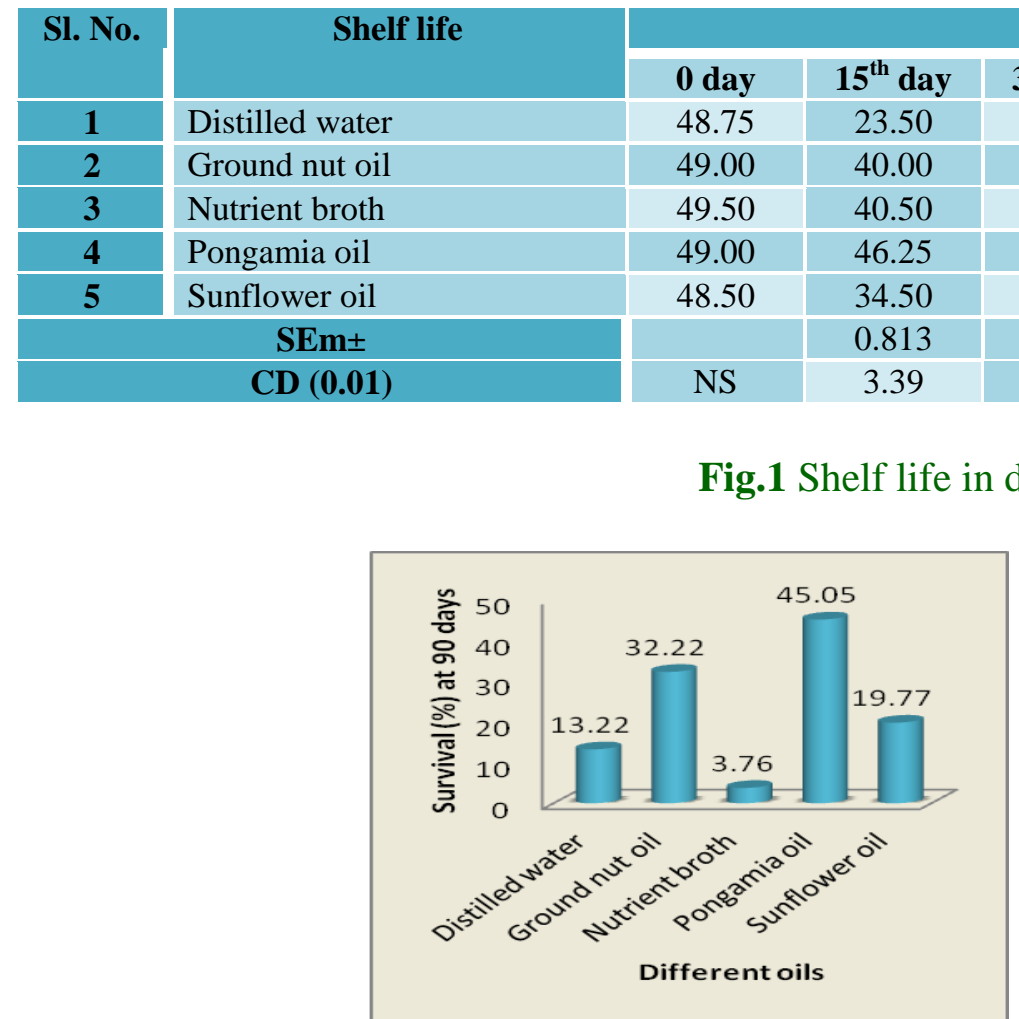

Fig.1a Bacillus subtilis $x 10^{6} \mathrm{CFU} / \mathrm{g}$ of formulation

\begin{tabular}{|c|c|c|c|c|}
$\mathbf{3 0}^{\text {th }} \mathbf{d a y}$ & $\mathbf{4 5}^{\text {th }} \mathbf{d a y}$ & $\mathbf{6 0}^{\text {th }} \mathbf{d a y}$ & $\mathbf{7 5}^{\text {th }} \mathbf{d a y}$ & $\mathbf{9 0}^{\text {th }} \mathbf{d a y}$ \\
\hline 19.50 & 18.50 & 13.50 & 11.50 & 7.75 \\
\hline 35.25 & 31.75 & 22.75 & 16.00 & 13.50 \\
\hline 26.50 & 16.00 & 10.75 & 3.50 & 1.50 \\
\hline 41.00 & 36.00 & 30.25 & 19.50 & 15.25 \\
\hline 31.00 & 26.70 & 19.00 & 14.50 & 12.25 \\
\hline 0.87 & 0.92 & 0.88 & 0.81 & 0.76 \\
\hline 3.66 & 3.85 & 3.69 & 3.40 & 3.18 \\
\hline
\end{tabular}

Survival \%

15.90

27.55

3.03

31.12

25.26 


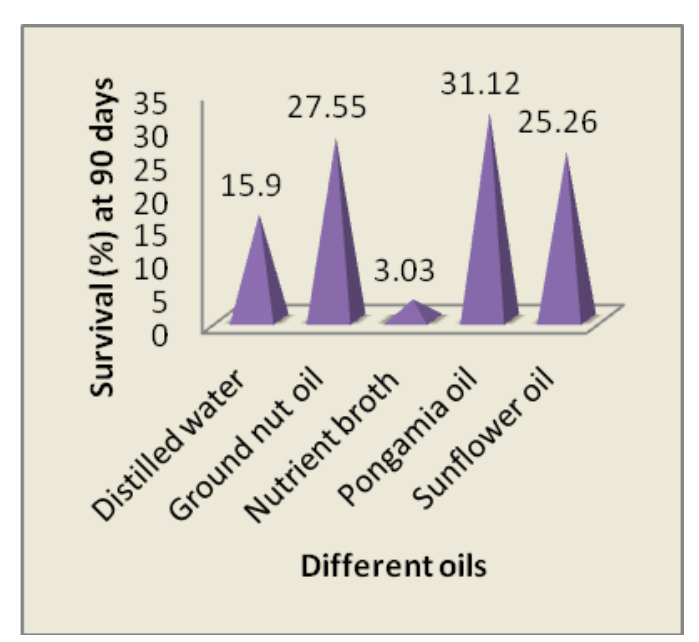

Fig.1c Brevibacillus sp.

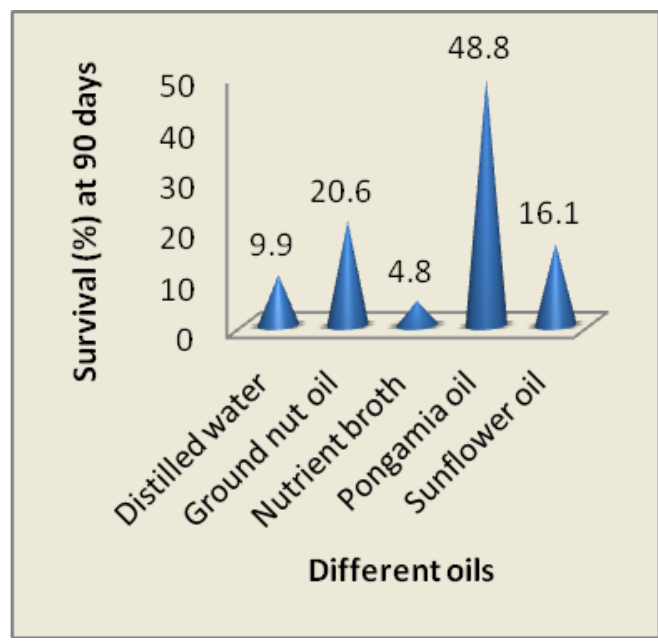

Fig.1d Lysinibacillus xylanilyticus

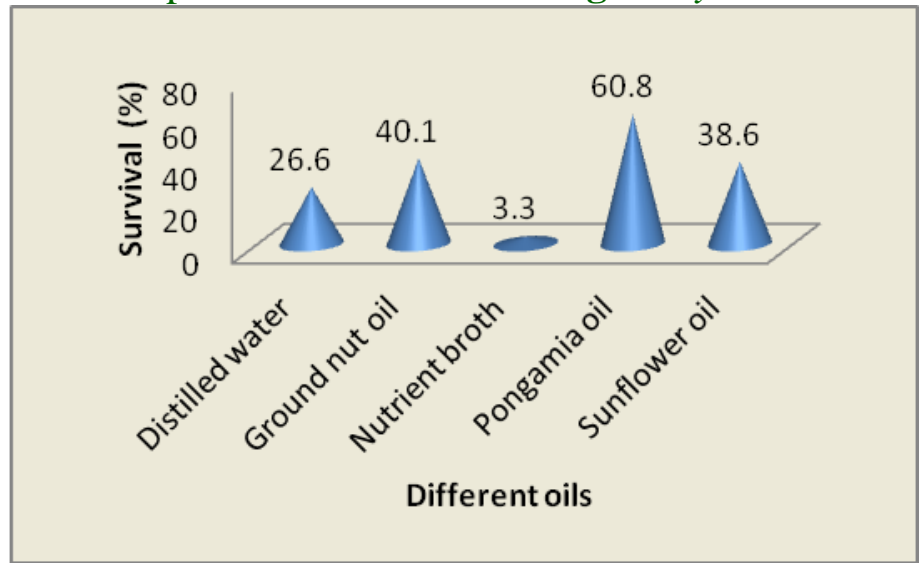

Fig.1e Consortium

Among the tested formulation the pongamia oil and ground oil were found significant. The highest number of colonies (20.25) was recorded in case of pongamia oil, where the initial count was 41.50. However the colony count declined from initial count to 33.25 , $31.00,25.75,25.00,21.50$ and 20.25 at $15^{\text {th }}$, $30^{\text {th }}, 45^{\text {th }}, 60^{\text {th }}$ and $75^{\text {th }}$ day respectively.

The next best treatment groundnut oil recorded the 8.50 colonies @ $90^{\text {th }}$ day where the initial count recorded was 41.25.

The sunflower oil recorded the 6.50 colonies at the $90^{\text {th }}$ day and found on par with the ground nut oil and distilled water. The distilled water recorded the 4.00 colonies at the $90^{\text {th }}$ day which was on par with the 2.00 colonies as observed.
The survival per cent was recorded for the Brevibacillus sp. on the he liquid formulations.

As per the recorded observations the pongamia oil showed highest survival (8.80 $\%$ ) followed by ground nut oil (20.6per cent) sunflower oil (16.1per cent), distilled water (9.9per cent) and nutrient broth (4.8per cent).

\section{Lysinobacillus xylaniticuIs}

The Lysinobacillus xylaniticuIs when tested for the shelf life in different liquid formulations the pongamia oil recorded the highest CFU (22.50) at $90^{\text {th }}$ day where the initial count recorded was $32.00 \mathrm{CFU}$, and the data presented in the table 5. The colony count declined from initial count to $35.75,31$. 
$25,24.50$, at $15^{\text {th }}, 30^{\text {th }}, 45^{\text {th }}$ day respectively and after which no change was observed in CFU till the $90^{\text {th }}$ day. The ground nut oil was proven as second best treatment with CFU of the 14.75 at $90^{\text {th }}$ day and varied significantly from pongamia oil. However, the Sunflower oil was found on par with the ground nut oil where $14.00 \mathrm{CFU}$ recorded at $90^{\text {th }}$ day.

The distilled water and nutrient broth recorded the 9.50 and $1.25 \mathrm{CFU}$ at $90^{\text {th }}$ day respectively and varied significantly from each other. The pongamia oil showed the highest survival per cent of 60.8 followed by Groundnut oil (40\%), sunflower (38.6per cent) distilled water (26.6per cent) and nutrient broth $(3.30 \%)$.

\section{Consortium}

Shelf life of bacterial consortium was tested up to 90 days on different liquid formulations and observation recorded is presented in the table 6 . With regard to consortium pongamia oil was found best with $15.25 \mathrm{CFU}$ at $90^{\text {th }}$ day where the initial count was 49.00 .

The colony count declined from initial count to $46.25,41.00,36.00,30.25,19.50,15.25$ @ $15^{\text {th }}, \quad 30^{\text {th }}, \quad 45^{\text {th }}, \quad 60^{\text {th }}, \quad 75^{\text {th }}, \quad 90^{\text {th }}$ day respectively.

The pongamia oil was found on par with Ground nut oil where the CFU recorded at $90^{\text {th }}$ day was 13.50. The sun flower oil recorded the $12.25 \mathrm{CFU}$ and was found to be on par with the ground nut oil. The treatments such as distilled water and nutrient broth showed 7.75 and $\mathrm{CFU}$ at $90^{\text {th }}$ day respectively.

The highest survival per cent of consortium observed in the pongamia oil (31.27 per cent) followed by Ground nut oil (27.55 per cent), sunflower (25.26 per cent) distilled water (15.9 per cent) and nutrient broth $(3.30 \%)$.
Mainly researchers confirmed that the formulations of microbial biomass developed as biological control products grown in different liquid media of differing composition shown extended shelf life (Sathiyaseelan et al., 2009 and Krishan and Greep, 2010).

Many workers while working with various bioagents have proved that their shelf life has improved significantly when these organisms are mixed with different oils/liquids in place of solid based substrates.

Moore et al., (1995) proved that long term storability of Metarrhizium flavoviride in oils such as soya and groundnut or mineral oil retaining 47 to 68 per cent viability and was after 16 to 18 months of storage.

Similarly, Ramyabharathi et al., (2016), formulated the B. subtilis using the chemical amendments glycerol and trehalose for increasing the shelf life, in that addition of glycerol to SOC broth recorded higher level of sporulation throughout the period of 365 days. The least sporulation was observed in broth alone.

Overall, our study was showed the liquid formulation helps in retaining higher count of viable population was found in pongamia oil followed by ground nut oil, sunflower oil, distilled water, nutrient broth upto 90 days. The pongamia oil retains the highest per cent survival of Bacillus subtilis (45.05), Brevibacillus borstelensis (32.93), Brevibacillus sp (48.80), Lysinibacillus xylanilyticus (60.00) and consortium (31.12).

\section{References}

Cook, R. J. and Baker, K. F., 1983, The nature and practice of biological control of plant pathogens. APS Press, St. Paul, USA, pp. 539. 
Harman, G. E., 1991, Seed treatment for biological control of plant diseases, Crop. Protec., 10:166-171.

Hegde, S.V., 2002. Liquid biofertilizers in Indian agriculture. Biofertilizer News Letter 12, 17-22.

Ippikoppa, R., 2015, Biological management of Xanthomonas axonopodis pv. punicae (Hingorani and Singh) Vauterin et al., causing bacterial blight of punica granatum L.. M.Sc thesis, Univ. of Hortic. Sci., Bagalkot. Karnataka.

Krishan, C. and Greep, S. 2010. Liquid based bio-fertilizers. J. Ecofriendly Agric., 5(1): 1-7.

Moore, D., Bateman, R. P., Carey, M. and Prior, C. 1995, Long-term storage of Metarhizium flavoviride conidia in oil formulations for the control of locusts and grasshoppers. Biocontrol. Sci. Technol., 5 (2): 193-199.

Sathiyaseelan, K., Sivasakthivelan, P. and Lenin, G., 2009, Evaluation of antagonistic activity and shelf life study of Trichoderma viride. Bot. Res. Int., 2 (3): 195-197.

Vendan, R.T., Thangaraju, M., 2006. Development and standardization of liquid formulation for Azospirillum bioinoculant. Indian Journal of Microbiology 46, 379-387.

Warriner, K. and Waites W.M., 1999, Enhanced sporulation in Bacillus subtilis grown on medium containing glucose: ribose. Applied Microbiology, 29: 97-102.

Yenjerappa, S. T., Nargund, V. B., Byadagi, A. S., Ravikumar, M. R., Mokashi, A. N. and Basavana G. K., 2013, Biological management of bacterial blight of pomegranate caused by Xanthomonas axonopodis pv. punicae. Karnataka J. Agric. Sci., 26 (4): 561562.

\section{How to cite this article:}

Jayasudha, S.M., K.C. Kirankumar, R.K. Mesta and Ramesh Ippikoppa. 2018. Liquid Formulation Using Different Oils and Shelf Life Study of Effective Bacterial Bio-Agents. Int.J.Curr.Microbiol.App.Sci. 7(04): 317-324. doi: https://doi.org/10.20546/ijcmas.2018.704.036 